\title{
Production responses of dairy cows when fed supplemental fat in low- and high-forage diets
}

\author{
W. P. Weiss ${ }^{1}$ and J. M. Pinos-Rodríguez ${ }^{2}$ \\ Department of Animal Sciences, Ohio Agricultural Research and Development Center, The Ohio State University, Wooster 44691
}

\begin{abstract}
Intake of net energy for lactation $\left(\mathrm{NE}_{\mathrm{L}}\right)$ is often the limiting factor for milk production and is affected by stage of lactation and dietary concentrations of forage and fat. Because of the mechanisms involved, interactions are likely between those 2 diet components and stage of lactation. We conducted an experiment with 72 Holstein cows starting at 21 and ending at $126 \mathrm{~d}$ in milk (DIM). Cows were fed diets (dry matter basis) with 40 or $60 \%$ forage ( $67 \%$ corn silage, $33 \%$ alfalfa silage) each with 0 or $2.25 \%$ added saturated free fatty acids. The high- and low-forage diets contained 25 and $17 \%$ forage neutral detergent fiber and 30 and $33 \%$ total neutral detergent fiber, respectively; the low-forage diets contained several byproducts. Diets with and without fat contained approximately 5.2 and $3.2 \%$ long-chain fatty acids, respectively. Feeding fat or low-forage diets increased $\mathrm{NE}_{\mathrm{L}}$ intake, but no interaction was observed. The increase in $\mathrm{NE}_{\mathrm{L}}$ intake by cows fed low-forage diets was caused by increased dry matter intake, and the increase in $\mathrm{NE}_{\mathrm{L}}$ intake by cows fed fat was caused by increased energy density of the diet. Interactions between fat and forage were observed for energy utilization. When high-forage diets were supplemented with fat, the increased $\mathrm{NE}_{\mathrm{L}}$ intake went toward body energy reserves as measured by higher body condition scores with no change in milk yield. However, when low-forage diets were supplemented with fat, milk yield increased $(2.6 \mathrm{~kg} / \mathrm{d})$ with no change in body condition. The differential partitioning of $\mathrm{NE}_{\mathrm{L}}$ may have been caused by nutrients other than $\mathrm{NE}_{\mathrm{L}}$ limiting milk production in cows fed the high-forage diets. With low-forage diets, intake of other nutrients was greater (i.e., greater dry matter intake). At 35 DIM, dietary treatments had little effect on milk fatty acids composition but in later lactation (125 DIM), feeding supplemental fatty acids or feeding low-forage diets increased long-chain fatty acids
\end{abstract}

\footnotetext{
Received July 9, 2009.

Accepted September 2, 2009.

${ }^{1}$ Corresponding author: weiss.6@osu.edu

${ }^{2}$ Current address: Instituto de Investigación de Zonas Deserticas, Universidad Autónoma de San Luis Potosí, Altair No. 200, Fracc. del Llano, 78377 San Luis Potosí, SLP, Mexico.
}

and decreased short-chain fatty acids. However, treatment did not have marked effects on concentrations of total fat or protein in milk. The amount of forage in a diet influences cow responses to supplemental fat and should be considered when diets are formulated.

Key words: forage, fiber, supplemental fat, energy intake

\section{INTRODUCTION}

Supplemental fat may be added to diets to meet the $\mathrm{NE}_{\mathrm{L}}$ requirement of a cow within fiber and NFC constraints or to increase the $\mathrm{NE}_{\mathrm{L}}$ intake of cows. In some situations, supplemental fat might be a more economical source of $\mathrm{NE}_{\mathrm{L}}$ than other ingredients. Replacing digestible carbohydrate with digestible fat increases the $\mathrm{NE}_{\mathrm{L}}$ concentration in a diet because fat has much higher gross energy and the efficiency of converting digestible energy from fat to $\mathrm{NE}_{\mathrm{L}}$ is higher. However, at recommended maximum inclusion rates $(\sim 4 \%)$, supplemental fat increases dietary $\mathrm{NE}_{\mathrm{L}}$ concentrations by only about $5 \%$. This means that a very modest $5 \%$ decrease in DMI will cancel the increase in $\mathrm{NE}_{\mathrm{L}}$ concentration, resulting in no increase in $\mathrm{NE}_{\mathrm{L}}$ intake. Therefore, understanding effects of fat supplementation on DMI under a range of conditions is necessary to develop appropriate supplementation strategies.

Numerous dietary and cow factors and interactions affect DMI. Conrad et al. (1964) described the general framework of intake regulation by dairy cows, which is still applicable today. Basically, they described a 2-phase control system in which either gut fill or energy demands regulated intake. Gut fill is a function of size of the cow and size of the rumen and gastrointestinal tract. Energy demand is a function of BW, milk production, and stage of lactation or gestation (i.e., differential partitioning of energy to milk or body reserves). In early lactation, cows are usually in negative energy balance, suggesting that fill, not energy demand, regulates intake. In mid to late lactation, cows usually are in positive energy balance, suggesting that energy demand, not fill, regulates DMI. Supplemental fat can affect DMI differently depending on stage of lactation (Chilliard, 1993; Drackley et al., 1998; Onetti and Grummer, 2004). 
Dietary factors also determine whether DMI is limited by fill or energy supply. Diets that are less digestible tend to fill up the digestive tract so that gut fill is the limiting factor. In almost all studies in which the concentration of dietary NDF is increased by the addition of forage, DMI is decreased (Allen, 2000). Supplementing fat, especially unsaturated fat, induces various hormonal and metabolic signals in cows that reduce DMI (Relling and Reynolds, 2007). However, fat supplementation usually maintains or increases $\mathrm{NE}_{\mathrm{L}}$ intake (Chilliard, 1993; Onetti and Grummer, 2004). Because forage and fat affect different intake regulators, fat supplementation could affect DMI differently depending on the concentration of forage fiber in the diet.

We hypothesized that feeding supplemental fat in a high-forage diet would increase $\mathrm{NE}_{\mathrm{L}}$ intake but not affect DMI because gut fill would be the primary regulator of DMI. Conversely, when fat was added to a low-forage diet, DMI would be reduced but $\mathrm{NE}_{\mathrm{L}}$ intake would remain essentially unchanged because energy demand would be the primary driver of intake. The net result is that with high-forage diets, supplemental fat would increase milk production and with low-forage diets, supplemental fat would increase feed efficiency (i.e., more milk per unit of DMI). The interaction between forage and fat should be greatest in early lactation (when fill is most likely to limit intake) and become less as lactation progresses and DMI increases. The objective of this experiment was to determine effects on intake and production when cows in early lactation were fed low- and high-forage diets with and without supplemental fat.

\section{MATERIALS AND METHODS}

\section{Cows and Treatments}

During late gestation, 72 Holsteins were blocked into groups of 4 based on parity (20 heifers and 52 cows) and calving date. Within each block, an animal was assigned randomly to 1 of 4 diets (Tables 1 and 2). Diets contained either 40 or $60 \%$ forage (DM basis) and either 0 or $2.25 \%$ added free, mostly saturated, fatty acids (Energy Booster 100, Milk Specialties Global, Carpentersville, IL). Diets were formulated so that the added fat replaced starch. Three days after calving, cows were moved to tie stalls and fed a preliminary diet (Table 1) for approximately $3 \mathrm{wk}$ (covariate period). On Wednesday of each week, all cows that were between 18 and 24 DIM were switched to their respective treatment diets and fed those diets for the next $15 \mathrm{wk}$. The preliminary diet contained $55 \%$ forage and $0.85 \%$ supplemental fat. The forage portion of all diets was
$67 \%$ corn silage and $33 \%$ alfalfa silage. The concentrates fed in the low-forage diets contained several high-fiber byproducts to increase the concentration of total NDF in order to compensate for the lower concentration of forage NDF and to reduce dietary starch concentrations. All diets were similar in concentrations of RDP, RUP, minerals, and vitamins and met or exceeded NRC (2001) requirements. Cows were fed once daily to achieve approximately $5 \%$ orts.

\section{Sampling and Measurements}

Feed offered and refused were measured daily. Orts were sampled from each cow once every 2 wk and analyzed for DM $\left(100^{\circ} \mathrm{C}\right.$ for $\left.24 \mathrm{~h}\right)$ to calculate DMI. Cows were milked twice daily and yields were recorded electronically. Cows were weighed and body condition scored (1-5 scale) at the start of the preliminary period, at the start of the treatment period, and then every 3 wk. The BCS was evaluated by 3 independent evaluators. Samples of silages, hay, and concentrates were taken weekly, stored in the freezer $\left(-20^{\circ} \mathrm{C}\right)$, and then composited by month $(\mathrm{n}=11)$. Each week, DM was measured in a subsample of each silage $\left(100^{\circ} \mathrm{C}\right.$ for $24 \mathrm{~h}$ ) to adjust diets for changes in DM. Composited silage samples were dried in a forced-air oven at $55^{\circ} \mathrm{C}$ for $48 \mathrm{~h}$ and all samples were ground through a 1-mm screen (Wiley mill, Arthur H. Thomas, Philadelphia, PA). Ground samples were analyzed for DM $\left(100^{\circ} \mathrm{C}\right.$ oven for $24 \mathrm{~h}$ ), NDF (Ankom200 Fiber Analyzer, Ankom Technology, Fairport, NY) with sodium sulfite and amylase (Ankom \#FAA, Ankom Technology), CP (Kjeldahl $\mathrm{N} \times 6.25)$, long-chain fatty acids (Weiss and Wyatt, 2003), and ash (AOAC, 2000). Starch concentrations were measured (Weiss and Wyatt, 2000) in 4 samples of each feed (approximately every other month composite). Milk (a.m. and p.m.) was sampled every Tuesday from all cows that were $>3$ DIM and analyzed for concentrations of milk fat, protein, lactose (B2000 Infrared Analyzer, Bentley Instruments, Chaska, MN), and MUN (Skalar SAN Plus segmented flow analyzer, Skalar Inc., Norcross, GA) by DHI Cooperative Inc. (Columbus, $\mathrm{OH}$ ). Additional a.m. and p.m. milk samples were taken at 2,8 , and 15 wk of the experimental period. The a.m. and p.m. milk samples were composited based on milk yield and analyzed for milk fatty acids (Weiss and Wyatt, 2003).

\section{Calculations and Statistics}

Daily DMI and milk production data were averaged by cow for the preliminary period. During the treatment period, DMI and milk yields and composition data were averaged into 3 -wk periods ( 5 periods per 
Table 1. Ingredient composition of preliminary (Prelim) and experimental diets

\begin{tabular}{|c|c|c|c|c|c|}
\hline \multirow[b]{2}{*}{ Item } & \multirow[b]{2}{*}{ Prelim } & \multicolumn{2}{|c|}{ High forage } & \multicolumn{2}{|c|}{ Low forage } \\
\hline & & - Fat & + Fat & - Fat & + Fat \\
\hline Corn silage & 36.8 & 40.0 & 40.0 & 26.8 & 26.8 \\
\hline Alfalfa silage & 18.2 & 20.0 & 20.0 & 13.2 & 13.2 \\
\hline Saturated fatty acids ${ }^{1}$ & 0.85 & - & 2.25 & - & 2.25 \\
\hline Ground corn & 18.25 & 20.90 & 18.12 & 20.80 & 17.30 \\
\hline Hominy & 1.5 & - & - & 4.0 & 4.0 \\
\hline Soybean hulls & 3.5 & - & - & 8.9 & 9.5 \\
\hline Wheat middlings & 2.6 & - & - & 7.0 & 7.0 \\
\hline Soybean meal, $44 \% \mathrm{CP}$ & 11.1 & 13.5 & 13.9 & 8.7 & 9.3 \\
\hline Treated soybean meal ${ }^{2}$ & 2.1 & 1.4 & 1.4 & 3.4 & 3.4 \\
\hline Distillers grains $^{3}$ & 3.0 & 2.0 & 2.0 & 5.0 & 5.0 \\
\hline Limestone & 0.90 & 0.87 & 0.94 & 1.08 & 1.13 \\
\hline Dicalcium phosphate & 0.10 & 0.20 & 0.21 & - & - \\
\hline Magnesium oxide & 0.05 & 0.04 & 0.09 & 0.03 & 0.03 \\
\hline Trace mineral salt & 0.49 & 0.49 & 0.49 & 0.49 & 0.49 \\
\hline Trace nutrient premix ${ }^{4}$ & 0.56 & 0.60 & 0.60 & 0.60 & 0.60 \\
\hline
\end{tabular}

${ }^{1}$ Energy Booster 100 (Milk Specialties Global, Carpentersville, IL).

${ }^{2}$ Surepro (LignoTech USA, Inc., Rothschild, WI).

${ }^{3}$ Dakota Gold HP (Poet Nutrition, Sioux Falls, SD).

${ }^{4}$ Contained copper sulfate, sodium selenate, zinc sulfate, biotin, and vitamins A, D, and E and was formulated to provide $9 \mathrm{mg}$ of $\mathrm{Cu}, 13 \mathrm{mg}$ of $\mathrm{Zn}, 0.3 \mathrm{mg}$ of Se, $1 \mathrm{mg}$ of biotin, 3,600 IU of vitamin A, 1,080 IU of vitamin $\mathrm{D}$, and $20 \mathrm{IU}$ of vitamin $\mathrm{E} / \mathrm{kg}$ of TMR DM.

cow). Body condition scores from the 3 evaluators were averaged. Gross efficiency was calculated by dividing period average milk yield by average DMI. Data were analyzed using the MIXED procedure (SAS Institute, 2004). The model included block (random, $17 \mathrm{df}$ ), forage (fixed, $1 \mathrm{df}$ ), fat (fixed, $1 \mathrm{df}$ ), forage $\times$ fat interac- tion ( $1 \mathrm{df}$ ), period (fixed repeated measure, $4 \mathrm{df}$ ), and period $\times$ treatment interactions (forage $\times$ period, fat $\times$ period, and forage $\times$ fat $\times$ period; fixed, total of 12 df). For production variables, the corresponding value measured during the preliminary period was used as a covariate when significant $(P<0.05)$. When a 2 -way

Table 2. Nutrient composition of the diets (DM basis)

\begin{tabular}{|c|c|c|c|c|}
\hline \multirow[b]{2}{*}{ Item, $\%$ unless otherwise noted } & \multicolumn{2}{|c|}{ High forage } & \multicolumn{2}{|c|}{ Low forage } \\
\hline & - Fat & + Fat & - Fat & + Fat \\
\hline DM & 59.8 & 60.1 & 69.5 & 69.7 \\
\hline $\mathrm{OM}$ & 93.3 & 93.1 & 94.0 & 93.9 \\
\hline $\mathrm{CP}$ & 17.5 & 17.7 & 17.1 & 17.1 \\
\hline NDF & 30.3 & 30.1 & 33.7 & 33.5 \\
\hline Forage NDF & 25.4 & 25.4 & 16.9 & 16.9 \\
\hline Starch & 29.3 & 26.6 & 28.0 & 25.1 \\
\hline NFC & 41.6 & 39.3 & 38.8 & 36.8 \\
\hline $\mathrm{NE}_{\mathrm{L}},{ }^{1} \mathrm{Mcal} / \mathrm{kg}$ & 1.62 & 1.67 & 1.60 & 1.66 \\
\hline Long-chain fatty acids (FA) & 2.9 & 5.0 & 3.4 & 5.5 \\
\hline $12: 0, \%$ of $\mathrm{FA}$ & 1.7 & 1.0 & 1.1 & 0.6 \\
\hline $14: 0, \%$ of $\mathrm{FA}$ & 0.2 & 1.6 & 0.1 & 1.5 \\
\hline $16: 0, \%$ of $\mathrm{FA}$ & 14.1 & 24.1 & 14.0 & 23.6 \\
\hline $18: 0, \%$ of $\mathrm{FA}$ & 3.0 & 19.8 & 2.8 & 19.0 \\
\hline $18: 1, \%$ of $\mathrm{FA}$ & 17.6 & 13.6 & 19.6 & 14.9 \\
\hline $18: 2, \%$ of $\mathrm{FA}$ & 40.8 & 24.4 & 45.6 & 27.5 \\
\hline $18: 3, \%$ of $\mathrm{FA}$ & 7.7 & 4.6 & 6.1 & 3.9 \\
\hline Others, ${ }^{2} \%$ of FA & 14.9 & 10.9 & 10.7 & 9.0 \\
\hline $\mathrm{Ca}$ & 0.98 & 1.10 & 1.00 & 0.98 \\
\hline $\mathrm{P}$ & 0.35 & 0.35 & 0.36 & 0.35 \\
\hline $\mathrm{Mg}$ & 0.25 & 0.26 & 0.25 & 0.24 \\
\hline $\mathrm{K}$ & 1.40 & 1.39 & 1.26 & 1.25 \\
\hline
\end{tabular}

${ }^{1}$ Calculated using NRC (2001) with treatment-average DMI and actual nutrient composition data.

${ }^{2}$ Includes fatty acids that comprised less than $1 \%$ of total fatty acids (in all diets) and unknown fatty acids (unknown fraction comprised about $85 \%$ of others). 
Table 3. Effect of dietary fat and forage:concentrate ratio on intake and production of lactating cows from 21 to 126 DIM

\begin{tabular}{|c|c|c|c|c|c|c|c|}
\hline \multirow[b]{2}{*}{ Measure $^{1}$} & \multicolumn{2}{|c|}{$60: 40$ ratio } & \multicolumn{2}{|c|}{ 40:60 ratio } & \multirow[b]{2}{*}{ SEM } & \multicolumn{2}{|r|}{ Effect $^{1}$} \\
\hline & - Fat & + Fat & - Fat & + Fat & & Diet & Int \\
\hline $\mathrm{BW}, \mathrm{kg}$ & 625 & 632 & 644 & 630 & 13.1 & - & - \\
\hline DMI, $\mathrm{kg} / \mathrm{d}$ & 22.9 & 23.5 & 24.9 & 24.7 & 0.58 & $\mathrm{R}$ & $\mathrm{FP}, \mathrm{RFP}$ \\
\hline $\mathrm{NE}_{\mathrm{L}}$ intake, $\mathrm{Mcal} / \mathrm{d}$ & 35.5 & 38.5 & 38.0 & 40.5 & 0.90 & $\mathrm{R}, \mathrm{F}$ & FP, RFP \\
\hline $\mathrm{BCS}$ & $2.71^{* \dagger}$ & $2.91 *$ & $2.89 \dagger$ & 2.89 & 0.05 & $\mathrm{~F}$ & $\mathrm{RF}$ \\
\hline Milk, $\mathrm{kg} / \mathrm{d}$ & 45.4 & $44.8 \dagger$ & $45.8^{*}$ & $48.4 * \dagger$ & 1.14 & $\mathrm{R}$ & $\mathrm{rf}$ \\
\hline Milk/DMI & $1.97 \dagger$ & 1.92 & $1.88^{*} \dagger$ & $1.97^{*}$ & 0.044 & - & $\mathrm{RF}$ \\
\hline Fat, \% & 3.73 & 3.92 & 3.65 & 3.59 & 0.13 & - & $\mathrm{fp}$ \\
\hline Fat, $\mathrm{kg} / \mathrm{d}$ & 1.69 & 1.78 & 1.67 & 1.71 & 0.10 & - & -1 \\
\hline Protein, \% & 2.85 & 2.80 & 2.89 & 2.84 & 0.05 & - & - \\
\hline Protein, $\mathrm{kg} / \mathrm{d}$ & 1.29 & 1.27 & 1.33 & 1.37 & 0.05 & $\mathrm{R}$ & - \\
\hline Lactose, $\%$ & 4.74 & 4.70 & 4.80 & 4.80 & 0.05 & $\mathrm{r}$ & - \\
\hline Lactose, $\mathrm{kg} / \mathrm{d}$ & 2.14 & 2.13 & 2.21 & 2.33 & 0.05 & $\mathrm{R}$ & - \\
\hline $\mathrm{SCC}, \log 10 / \mathrm{mL}$ & 4.18 & 4.31 & 4.32 & 4.42 & 0.12 & - & RFP \\
\hline MUN, mg/dL & 14.4 & 15.4 & 12.5 & 13.3 & 0.33 & $\mathrm{~F}, \mathrm{R}$ & - \\
\hline
\end{tabular}

${ }^{1}$ Period ( 3 wk periods from wk 3 to 18 of lactation) and treatment by period interactions (Int) were included in repeated measures statistical analysis. All responses except lactose percentage were affected by period $(P<$ $0.05) . \mathrm{R}=$ forage:concentrate ratio effect; $\mathrm{F}=$ fat effect; $\mathrm{RF}, \mathrm{FP}$, and $\mathrm{RFP}=$ interactions between $\mathrm{R}$ and $\mathrm{F}, \mathrm{F}$ and period, and $\mathrm{R}, \mathrm{F}$, and period, respectively. Uppercase $=P<0.05$; lowercase $=P<0.10$.

*Within forage:concentrate main effect, fat treatment means differ $(P<0.05)$ based on SLICE option of SAS (SAS Institute, Cary, NC). Analysis conducted when interaction was significant $(P<0.10)$.

$\dagger$ Within fat main effect, forage:concentrate means differ $(P<0.05)$ based on SLICE option. Analysis conducted when interaction was significant $(P<0.10)$.

interaction was observed $(P<0.10)$, the SLICE option (SAS, 2004) was used to evaluate it. If a 3 -way interaction was observed $(P<0.10)$, data were analyzed by period and the SLICE option was used. The covariate structure that resulted in the lowest Akaike's information criterion was first-order autoregressive.

\section{RESULTS}

At the start of the preliminary period (3 DIM), average BW and BCS of the cows were $638 \pm 12 \mathrm{~kg}$ and 3.1 \pm 0.08 , respectively, and at the end of the preliminary period BW and BCS averaged $605 \pm 12 \mathrm{~kg}$ and 2.9 \pm 0.07 , respectively. During the experimental period, dietary treatment had no effect on BW and there were no interactions among main effects and between treatments and periods (Table 3). The nadir for BW occurred during period 1 (average DIM $=32$ ) and BW increased $(P<0.05)$ every successive period and averaged $659 \mathrm{~kg}$ at the end of the experiment (Figure 1). Body condition score was affected $(P<0.05)$ by fat, fat $\times$ forage interaction, and period (forage effect was $P<$ 0.11). Average (across treatments) BCS did not differ between periods 1 and $2(P<0.15)$ and then increased $(P<0.05)$ with every successive period through period 4 , when it reached a plateau (Figure 1). Feeding supplemental fat $(P<0.05)$ and feeding lower forage diets $(P$ $<0.11)$ increased BCS; however, the interaction $(P<$ $0.05)$ precludes discussion of the main effects (Table 3 ).
With high-forage diets, the addition of supplemental fat increased BCS $(P<0.05)$, but fat did not affect BCS with low-forage diets. Alternately, feeding a lowforage diet increased BCS $(P<0.05)$ when fat was not supplemented, but if fat was fed, concentration of forage had no effect on BCS.

Cows fed the low-forage diets had greater $(P<0.05)$ DMI than cows fed the high-forage diets ( 24.8 vs. 23.5 $\mathrm{kg} / \mathrm{d})$ and DMI increased $(P<0.01)$ from period 1 through period 5 (Table 3; Figure 2). Fat did not affect DMI $(P>0.3)$, but a fat $\times$ period interaction was observed $(P<0.01)$. Averaged across forage treatments, in periods 1 and 2, cows fed fat had higher DMI than those not fed fat, in periods 3 and 4, DMI was essentially equal, and in period 5, DMI was reduced when fat was fed. A forage $\times$ fat $\times$ period interaction was also observed $(P<0.05)$. During most of the experiment, cows fed high-forage diets with fat had greater DMI than cows fed high-forage diets without fat. When low-forage diets were fed, fat increased DMI in period 1 , had no effect in period 2, and reduced DMI during periods 3,4 , and 5 .

Intake of $\mathrm{NE}_{\mathrm{L}}$ (Table 3; Figure 3) was greater $(P<$ $0.01)$ when cows were fed supplemental fat and when cows were fed low-forage diets. Intake of $\mathrm{NE}_{\mathrm{L}}$ increased from period 1 through period 3 and then reached a plateau. Intake of $\mathrm{NE}_{\mathrm{L}}$ was much greater by cows fed fat than by cows not fed fat in early periods but the difference decreased as DIM progressed, resulting in a fat 


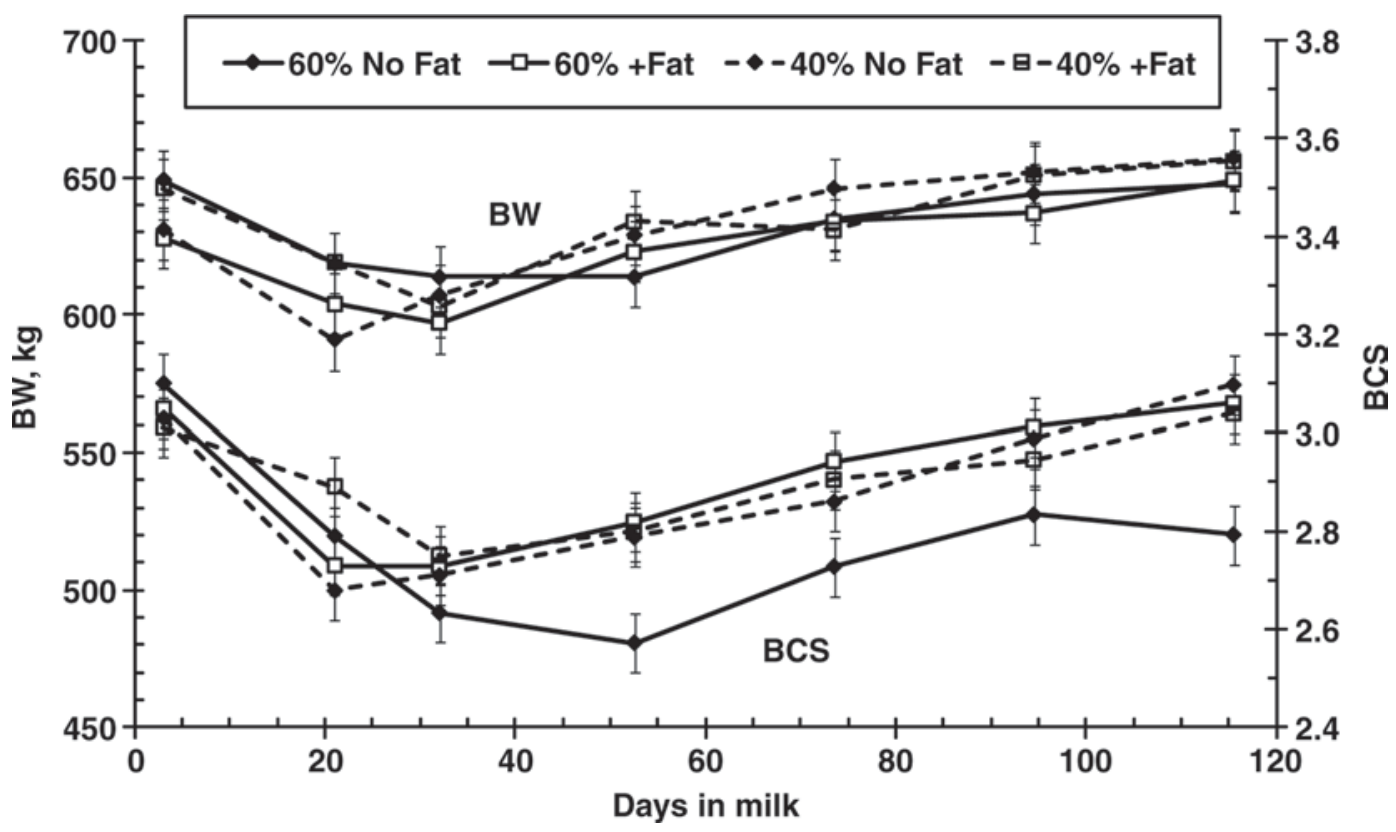

Figure 1. Change in BW and BCS ( $1=$ thin, $5=$ obese) over time for cows fed diets with 40 or $60 \%$ forage with 0 or $2.25 \%$ supplemental fat. The preliminary period was from 3 to 20 DIM and treatment diets started at 21 DIM. Time affected both measures $(P<0.05)$, but no time by diet treatment interactions were observed. Treatment had no effect on BW; however, BCS was affected $(P<0.05)$ by fat and the fat by forage interaction.

$\times$ period interaction $(P<0.05)$. The forage treatment affected the time when $\mathrm{NE}_{\mathrm{L}}$ intake for the fat treatments started to converge (i.e., the 3 -way interaction; $P<0.07)$. In low-forage diets, differences between fat treatments were large in period 1 , started to converge during period 2, and by period 3, differences were small. With the high-forage diets, differences between fat treatments remained constant until period 4 and then converged in period 5 .

On average, milk yields increased until about 56 DIM, remained constant through 70 DIM, and then started declining (Table 3; Figure 4). Because a forage $\times$ fat interaction was observed $(P<0.08)$, the main effects will not be discussed. Milk yields increased when fat

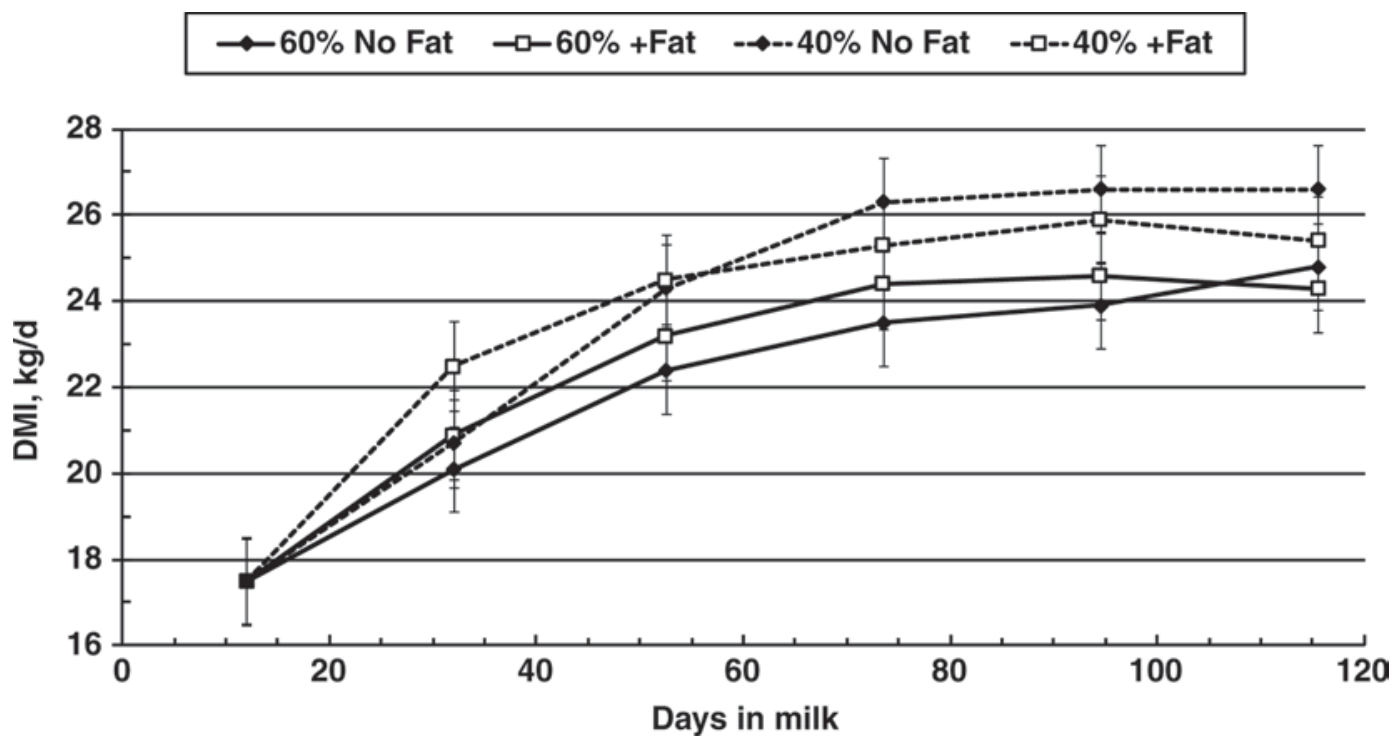

Figure 2. Covariate-adjusted DMI of cows fed diets with 40 or $60 \%$ forage with 0 or $2.25 \%$ supplemental fat. Treatment diets started at 21 DIM and preliminary period data were used as the covariate; the solid square is overall mean during that period. The DMI was affected $(P<$ $0.05)$ by time, forage, the fat by time interaction, and the fat by forage by time interaction. 


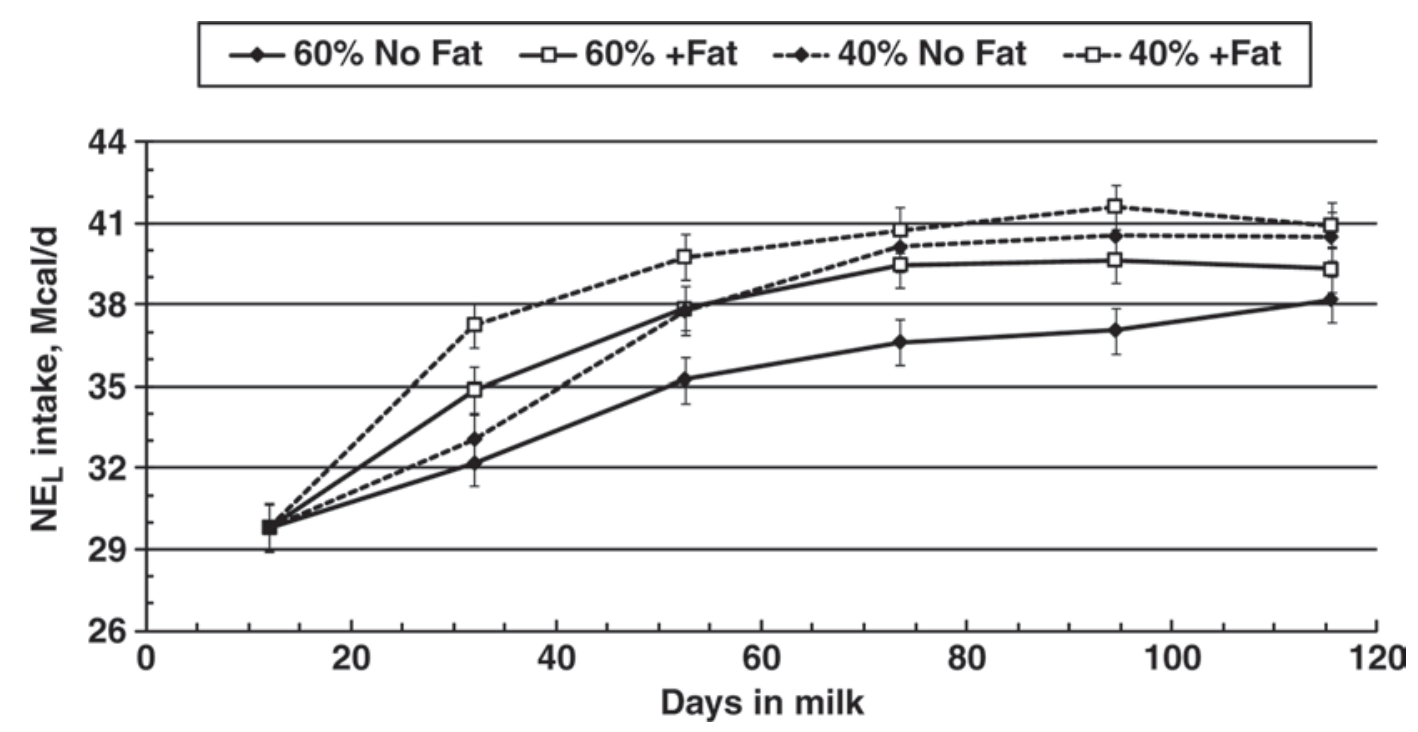

Figure 3. Covariate-adjusted intake of estimated (NRC, 2001) $\mathrm{NE}_{\mathrm{L}}$ by cows fed diets with 40 or $60 \%$ forage with 0 or $2.25 \%$ supplemental fat. Treatment diets started at 21 DIM and preliminary period data were used as the covariate; the solid square is overall mean during that period. Intake of $\mathrm{NE}_{\mathrm{L}}$ was affected $(P<0.05)$ by time, fat, forage, the fat by time interaction, and the fat by forage by time interaction.

was added to the low-forage diet but not when fat was added to the high-forage diet, resulting in the interaction. Alternatively, when fat was not fed, milk yields did not differ between forage treatments, but when diets contained supplemental fat, cows produced more milk $(P<0.05)$ when fed the low-forage diet than the high-forage diet. The interaction for milk was opposite that observed for BCS.

Feed efficiency (milk yield divided by DMI) was high because cows were in early lactation and mobilizing body energy reserves (Table 3). Efficiency averaged
2.13 during period 1 and decreased $(P<0.01)$ through each successive period, averaging 1.76 during period 5. No interactions between time and treatment were observed. Main effects did not affect efficiency, but a forage $\times$ fat interaction was observed $(P<0.05)$. Supplementing high-forage diets with fat did not affect feed efficiency, but feeding fat with low-forage diets increased feed efficiency.

Dietary treatment had no effect on concentrations of milk fat, protein, and lactose, but cows fed low-forage diets had greater $(P<0.05)$ yields of milk protein and

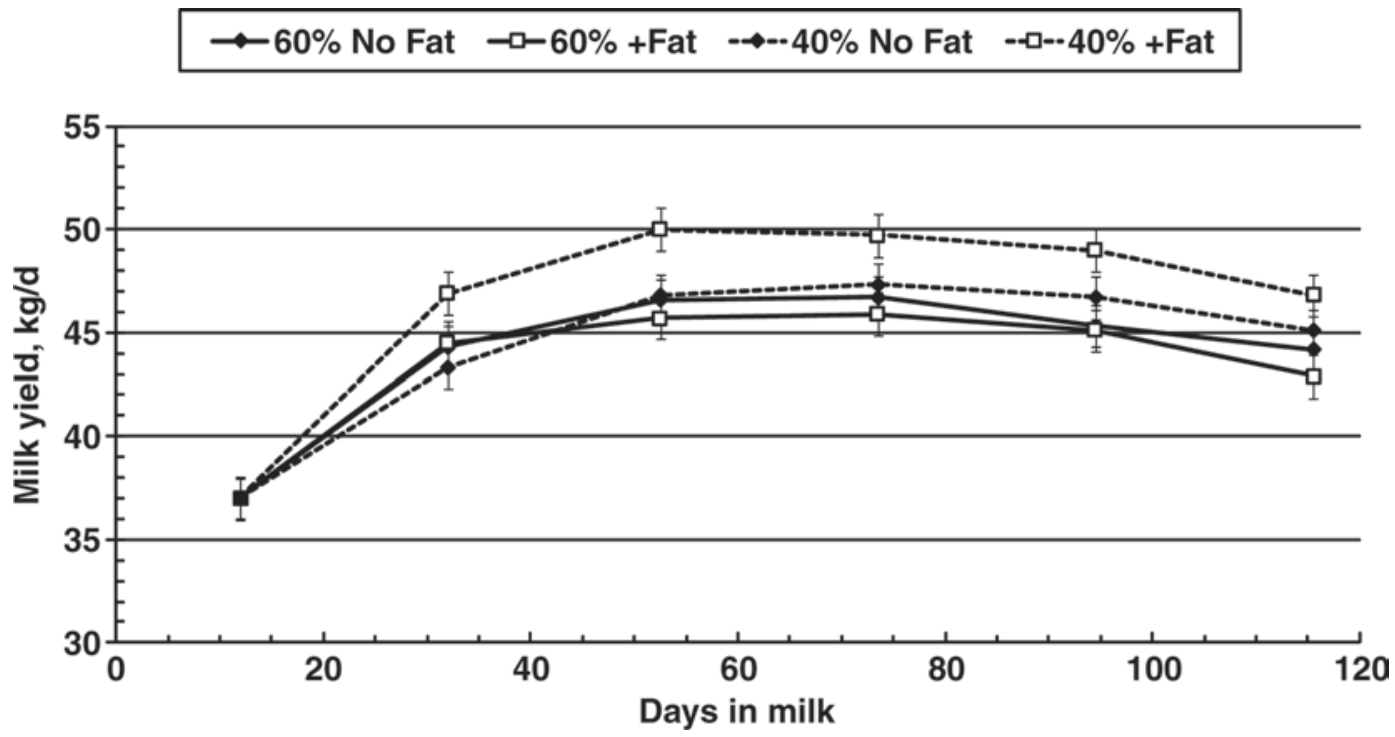

Figure 4. Covariate-adjusted milk yields by cows fed diets with 40 or $60 \%$ forage with 0 or $2.25 \%$ supplemental fat. Treatment diets started at 21 DIM and preliminary period data were used as the covariate; the solid square is overall mean during that period. Milk yield was affected by forage $(P<0.05)$ and the forage by fat interaction $(P<0.10)$. 
Table 4. Fatty acid composition of fat (\% of total fatty acids) from milk sampled during wk 2 of the experiment (approximately 35 DIM)

\begin{tabular}{|c|c|c|c|c|c|c|}
\hline \multirow[b]{2}{*}{ Fatty acid ${ }^{1}$} & \multicolumn{2}{|c|}{$60: 40$ ratio } & \multicolumn{2}{|c|}{ 40:60 ratio } & \multirow[b]{2}{*}{ SEM } & \multirow[b]{2}{*}{ Effect $^{2}$} \\
\hline & - Fat & + Fat & - Fat & + Fat & & \\
\hline 4:0 & 3.58 & 3.80 & 3.71 & 3.72 & 0.12 & - \\
\hline $6: 0$ & 2.69 & 2.71 & 2.58 & 2.63 & 0.09 & - \\
\hline $8: 0$ & 1.37 & 1.32 & 1.33 & 1.33 & 0.06 & - \\
\hline $10: 0$ & 2.90 & 2.67 & 2.78 & 2.84 & 0.15 & - \\
\hline $12: 0$ & 3.08 & 2.78 & 3.01 & 3.03 & 0.16 & - \\
\hline $14: 0$ & 9.84 & 9.73 & 9.89 & 9.89 & 0.40 & - \\
\hline $14: 1$ & 0.82 & 0.60 & 0.77 & 0.73 & 0.05 & $\mathrm{~F}, \mathrm{rf}$ \\
\hline 16:0 & 26.71 & 29.00 & 25.85 & 28.20 & 0.09 & $\mathrm{R}, \mathrm{F}$ \\
\hline $16: 1$ & 2.34 & 1.93 & 2.18 & 2.06 & 0.09 & $\mathrm{~F}, \mathrm{rf}$ \\
\hline 18:0 & 10.29 & 11.83 & 9.95 & 11.00 & 0.52 & $\mathrm{~F}$ \\
\hline $18: 1 t-6,8$ & 0.34 & 0.39 & 0.48 & 0.46 & 0.05 & $\mathrm{RF}$ \\
\hline $18: 1 t-9$ & 0.26 & 0.29 & 0.33 & 0.37 & 0.04 & $\mathrm{R}$ \\
\hline $18: 1 t-10$ & 0.97 & 0.98 & 1.60 & 1.56 & 0.31 & $\mathrm{R}$ \\
\hline $18: 1 \quad c-9$ & 25.50 & 23.22 & 25.54 & 22.78 & 1.03 & $\mathrm{~F}$ \\
\hline $18: 1 c-11$ & 1.14 & 0.86 & 1.20 & 0.97 & 0.08 & $\mathrm{R}, \mathrm{F}$ \\
\hline $18: 2$ & 3.49 & 3.19 & 4.07 & 3.89 & 0.14 & $\mathrm{R}, \mathrm{f}$ \\
\hline $18: 3$ & 0.65 & 0.61 & 0.64 & 0.64 & 0.02 & $\mathrm{f}$ \\
\hline$c-9, t-11$ CLA & 0.51 & 0.46 & 0.59 & 0.45 & 0.04 & $\mathrm{~F}$ \\
\hline SCFA & 24.3 & 23.6 & 24.0 & 24.2 & 0.83 & - \\
\hline LCFA & 44.7 & 43.5 & 46.0 & 43.5 & 1.17 & - \\
\hline
\end{tabular}

lactose than cows fed high-forage diets (Table 3). On average, milk fat percentage decreased $(P<0.05)$ as lactation progressed whereas protein concentrations increased $(P<0.05)$. A fat $\times$ period interaction was observed for milk fat percentage $(P<0.08)$. Milk fat percentage was greater for cows fed fat in all periods except period 1 , when it was greater for cows not fed supplemental fat (data not shown). No interactions among dietary treatments and period were observed for concentrations or yields of other milk components. A period effect and a 3 -way interaction were observed $(P$ $<0.05$ ) for SCC, but these probably just reflect random changes over time. The highest period-treatment average for SCC was 193,000 cells/mL (data not shown); therefore, mastitis was not an issue with any treatment. The concentration of MUN increased $(P<0.05)$ when fat was fed (14.4 vs. $13.4 \mathrm{mg} / \mathrm{dL})$ and when high-forage diets were fed (14.9 vs. $12.9 \mathrm{mg} / \mathrm{dL})$, but no interaction was observed.

The concentrations (\% of total fatty acids) of many milk fatty acids were affected by the forage and fat main effects and some forage $\times$ fat interactions were observed (Tables 4, 5, and 6). Most fatty acids were affected by stage of lactation and numerous interactions between diet and lactation stage were observed (Table 7). In general, the concentrations of short-chain
( $\leq 14 \mathrm{C})$ fatty acids (SCFA) and 16:0 increased markedly between 35 and 75 DIM and then were relatively constant. Conversely, concentrations of long-chain $(\geq 18$ C) fatty acids (LCFA) decreased markedly between 35 and 75 DIM and then were constant. At 35 DIM (cows were mobilizing significant body fat and DMI was low), the major effects of feeding fat were increased concentrations of 16:0 and decreased concentrations of the cis isomers of 18:1 (Table 4). At both 75 and 125 DIM (DMI and milk yields were maximal and cows were gaining BW), feeding supplemental fat generally reduced concentrations of SCFA and polyunsaturated fatty acids (18:2 and 18:3) and increased concentrations of 18:0 (Tables 5 and 6). The forage:concentrate ratio affected only a few fatty acids at 35 DIM; most notably, cows fed the high-forage diets had higher concentrations of 16:0 and lower concentrations of trans-10 18:1 and 18:2. At 75 DIM, the high-forage diet reduced concentrations of $18: 2$ and increased concentrations of 4:0. At 125 DIM, feeding the high-forage diet generally increased concentrations of SCFA and 16:0 and reduced concentrations of LCFA. Essentially, no fat $\times$ forage interactions were observed for fatty acids at 35 and 75 DIM. At 125 DIM, some interactions between fat and forage were observed, but mostly for minor fatty acids. 
Table 5. Fatty acid composition of fat (\% of total fatty acids) from milk sampled during wk 8 of the experiment (approximately 75 DIM)

\begin{tabular}{|c|c|c|c|c|c|c|}
\hline \multirow[b]{2}{*}{ Fatty acid ${ }^{1}$} & \multicolumn{2}{|c|}{$60: 40$ ratio } & \multicolumn{2}{|c|}{$40: 60$ ratio } & \multirow[b]{2}{*}{ SEM } & \multirow[b]{2}{*}{ Effect } \\
\hline & - Fat & + Fat & - Fat & + Fat & & \\
\hline $4: 0$ & 4.13 & 4.33 & 3.84 & 4.12 & 0.13 & $\mathrm{R}, \mathrm{F}$ \\
\hline $6: 0$ & 2.91 & 2.87 & 2.80 & 2.76 & 0.11 & - \\
\hline $8: 0$ & 1.60 & 1.48 & 1.58 & 1.44 & 0.07 & $\mathrm{~F}$ \\
\hline 10:0 & 3.79 & 3.29 & 3.89 & 3.27 & 0.17 & $\mathrm{~F}$ \\
\hline $12: 0$ & 4.41 & 3.62 & 4.54 & 3.60 & 0.20 & $\mathrm{~F}$ \\
\hline $14: 0$ & 12.7 & 11.9 & 13.1 & 11.6 & 0.23 & $\mathrm{~F}$ \\
\hline $14: 1$ & 1.23 & 0.91 & 1.21 & 0.98 & 0.08 & $\mathrm{~F}$ \\
\hline $16: 0$ & 30.10 & 32.0 & 29.6 & 31.0 & 0.58 & $\mathrm{~F}$ \\
\hline $16: 1$ & 2.07 & 1.90 & 1.91 & 1.90 & 0.10 & - \\
\hline $18: 0$ & 7.95 & 9.38 & 8.14 & 9.82 & 0.46 & $\mathrm{~F}$ \\
\hline $18: 1 t-6,8$ & 0.41 & 0.37 & 0.48 & 0.45 & 0.06 & - \\
\hline $18: 1 t-9$ & 0.29 & 0.29 & 0.33 & 0.33 & 0.03 & - \\
\hline $18: 1 t-10$ & 1.57 & 1.21 & 1.70 & 1.50 & 0.32 & - \\
\hline $18: 1 \quad c-9$ & 18.0 & 18.6 & 17.2 & 18.2 & 0.52 & - \\
\hline $18: 1 c-11$ & 0.77 & 0.70 & 0.79 & 0.71 & 0.05 & $\mathrm{~F}$ \\
\hline $18: 2$ & 3.19 & 2.79 & 4.11 & 3.73 & 0.15 & $\mathrm{R}, \mathrm{F}$ \\
\hline $18: 3$ & 0.58 & 0.53 & 0.57 & 0.56 & 0.02 & f \\
\hline$c-9, t-11$ CLA & 0.51 & 0.46 & 0.59 & 0.45 & 0.04 & $\mathrm{~F}$ \\
\hline SCFA & 30.7 & 28.4 & 31.0 & 27.7 & 0.66 & $\mathrm{~F}$ \\
\hline LCFA & 34.5 & 35.4 & 35.0 & 37.0 & 0.96 & $\mathrm{f}$ \\
\hline
\end{tabular}

\section{DISCUSSION}

\section{Energy Partitioning}

The treatments imposed in this experiment were expected to change energy supply via increased energy density (mostly a fat treatment effect) or via increased DMI (mostly a forage effect). As expected, cows fed the $40 \%$ forage diets had greater $(P<0.05)$ DMI than cows fed the $60 \%$ forage diet, probably because of the large difference in forage NDF between diets (Allen, 2000). Supplementing diets with fat had no effect on DMI averaged over the experiment, but during the first period (21 through 42 DIM) cows fed fat had greater $(P<0.05)$ DMI (Figure 2). A positive effect of supplemental fat on DMI in early lactation was also reported by Drackley et al. (1998). However, increased DMI in response to fat supplementation is not a usual response (see reviews Allen, 2000; Onetti and Grummer, 2004). The inclusion rate of supplemental fat used in our study was less than the average inclusion rate used in previous studies, which could affect DMI responses. Intake of estimated $\mathrm{NE}_{\mathrm{L}}$ followed the same general trends as DMI except that cows fed fat consumed more $(P<$ $0.05) \mathrm{NE}_{\mathrm{L}}$ than cows not fed fat (40.5 vs. $37.7 \mathrm{Mcal} / \mathrm{d}$ ). The increase in $\mathrm{NE}_{\mathrm{L}}$ intake when cows were fed fat was caused by increased energy density (fat increased estimated dietary $\mathrm{NE}_{\mathrm{L}}$ concentration by about $5 \%$;
Table 2); the increase in $\mathrm{NE}_{\mathrm{L}}$ intake when cows were fed the low-forage diets was caused by increased DMI. A change in the $\mathrm{NE}_{\mathrm{L}}$ intake can affect body energy stores or milk production, and diet had a substantial effect on partitioning the increased $\mathrm{NE}_{\mathrm{L}}$ intake. When cows were fed the low-forage diets, the increase in $\mathrm{NE}_{\mathrm{L}}$ intake caused by supplemental fat was largely partitioned to milk. This is based on similar BCS, increased milk yield, and increased milk per unit of DMI for cows fed the low-forage diet with fat compared with those fed the low-forage without fat diet (Table 3). Conversely, when cows were fed the $60 \%$ forage diet, the increase in $\mathrm{NE}_{\mathrm{L}}$ intake from supplemental fat largely went to body energy reserves because fat did not increase milk yield or change feed efficiency but increased BCS. This interaction may have been caused by a limitation of milk precursors (e.g., amino acids and glucose) when the high-forage diet was fed. Feeding supplemental fat would provide additional energy (i.e., ATP equivalents) but would not necessarily increase glucose synthesis or amino acid supply. The low-forage diet likely provided more glucose precursors because of greater DMI (as supported by increased milk lactose yield with the lowforage diet) and may have provided more amino acids (increased milk protein yield). This would allow the additional energy provided by fat to be directed toward milk synthesis. With the high-forage diets, energy was 
Table 6. Fatty acid composition of fat (\% of total fatty acids) from milk sampled during wk 15 of the experiment (approximately 125 DIM)

\begin{tabular}{|c|c|c|c|c|c|c|}
\hline \multirow[b]{2}{*}{ Fatty acid ${ }^{1}$} & \multicolumn{2}{|c|}{$60: 40$ ratio } & \multicolumn{2}{|c|}{ 40:60 ratio } & \multirow[b]{2}{*}{ SEM } & \multirow[b]{2}{*}{ Effect $^{2}$} \\
\hline & - Fat & + Fat & - Fat & + Fat & & \\
\hline $4: 0$ & 3.10 & 3.76 & 3.36 & 3.73 & 0.12 & $\mathrm{~F}, \mathrm{RF}$ \\
\hline $6: 0$ & 2.48 & 2.74 & 2.48 & 2.40 & 0.10 & $\mathrm{R}, \mathrm{rf}$ \\
\hline $8: 0$ & 1.40 & 1.42 & 1.37 & 1.26 & 0.06 & $\mathrm{r}$ \\
\hline 10:0 & 3.53 & 3.22 & 3.34 & 2.88 & 0.14 & $\mathrm{R}, \mathrm{F}$ \\
\hline $12: 0$ & 4.44 & 3.67 & 4.06 & 3.35 & 0.16 & $\mathrm{R}, \mathrm{F}$ \\
\hline 14:0 & 12.9 & 12.1 & 12.6 & 11.4 & 0.22 & $\mathrm{R}, \mathrm{F}$ \\
\hline $14: 1$ & 1.63 & 1.05 & 1.32 & 1.30 & 0.11 & $\mathrm{RF}$ \\
\hline $16: 0$ & 32.2 & 33.0 & 30.6 & 31.4 & 0.65 & $\mathrm{R}$ \\
\hline $16: 1$ & 2.52 & 2.06 & 2.19 & 2.45 & 0.16 & $\mathrm{RF}$ \\
\hline $18: 0$ & 6.76 & 9.11 & 8.16 & 9.15 & 0.41 & $\mathrm{R}, \mathrm{F}, \mathrm{RF}$ \\
\hline $18: 1 t-6,8$ & 0.48 & 0.40 & 0.41 & 0.47 & 0.04 & - \\
\hline $18: 1 t-9$ & 0.33 & 0.31 & 0.30 & 0.37 & 0.03 & $\mathrm{RF}$ \\
\hline $18: 1 t-10$ & 1.87 & 1.09 & 1.33 & 1.49 & 0.25 & $\mathrm{RF}$ \\
\hline $18: 1 c-9$ & 16.8 & 18.2 & 18.5 & 19.7 & 0.57 & $\mathrm{R}, \mathrm{F}$ \\
\hline $18: 1 c-11$ & 0.83 & 0.63 & 0.85 & 0.78 & 0.05 & $\mathrm{r}, \mathrm{F}$ \\
\hline $18: 2$ & 3.20 & 2.74 & 4.03 & 3.71 & 0.11 & $\mathrm{R}, \mathrm{F}$ \\
\hline $18: 3$ & 0.62 & 0.51 & 0.57 & 0.56 & 0.02 & $\mathrm{~F}, \mathrm{RF}$ \\
\hline$c-9, t-11$ CLA & 0.49 & 0.41 & 0.54 & 0.48 & 0.04 & $\mathrm{r}, \mathrm{F}$ \\
\hline SCFA & 29.5 & 28.0 & 28.5 & 25.9 & 0.54 & $\mathrm{R}, \mathrm{F}$ \\
\hline LCFA & 32.6 & 34.6 & 36.2 & 38.1 & 0.88 & $\mathrm{R}, \mathrm{F}$ \\
\hline
\end{tabular}

${ }^{1}$ Number of carbon atoms:number of double bonds $(c=c i s, t=$ trans $)$. CLA $=$ conjugated linoleic acid; SCFA $=$ short-chain fatty acids $(\leq 14 \mathrm{C}) ; \mathrm{LCFA}=$ long-chain fatty acids $(\geq 18 \mathrm{C})$.

${ }^{2} \mathrm{R}=$ forage:concentrate ratio effect; $\mathrm{F}=$ fat effect; $\mathrm{RF}=$ interaction between $\mathrm{R}$ and $\mathrm{F}$. Uppercase $=P<0.05$; lowercase $=P<0.10$

not the limiting factor for milk production; therefore, the added energy when fat was supplemented was diverted to body stores.

A study (Jerred et al., 1990) in which diets with 45 to $84 \%$ forage and 0 or $5 \%$ added prilled fat were fed to cows in early lactation found no interaction between forage and fat for milk production, energy balance, and BCS. In that study, supplemental fat reduced DMI resulting in no change in $\mathrm{NE}_{\mathrm{L}}$ intake whereas, in our study, feeding fat did not affect $\mathrm{DMI}$ and increased $\mathrm{NE}_{\mathrm{L}}$ intake. Similar to our results, feeding supplemental fat from soybeans increased feed efficiency with a diet containing 39\% forage but had no effect when fed with a diet containing 49\% forage (Grant and Weidner, 1992). However, unlike our study, they reported no effects of fat on milk production. Although the interaction was not significant $(P<0.05)$ in a Latin square experiment (Canale et al., 1990), supplementing Ca soaps (2.5\% of diet DM) in diets that contained $70 \%$ alfalfa had little effect on feed efficiency (1.48 and 1.53) whereas supplementing fat in diets with $50 \%$ alfalfa increased feed efficiency (1.32 and 1.47). Last, including 4\% Ca soaps in a diet with $50 \%$ forage increased FCM yield but had no effect when fed in a diet with $66 \%$ forage (Klusmeyer et al., 1991). The results of this and previous studies generally support the idea that with lower forage diets, energy provided by supplemental fat is partitioned to milk whereas when fed with higher forage diets, the energy is partitioned toward body energy reserves.

\section{Milk Composition}

The concentrations of major milk components were unaffected by dietary treatment. Although the lowforage diets contained only $16.7 \%$ forage NDF, milk fat concentration was not affected by forage treatment $(P<0.17)$. The low-forage diets were formulated to have more total NDF and less NFC compared with the high-forage diets as recommended by NRC (2001). A meta-analysis conducted by Onetti and Grummer (2004) found that supplementing the type of fat used in this experiment usually increased both concentration and yield of milk fat, but fat had no effect on milk fat concentration or yield in this experiment.

Dietary treatments did not affect milk fat yields and concentrations but they did affect numerous specific fatty acids (Tables 4, 5, and 6). General responses for groups of fatty acids, rather than specific fatty acids, will be discussed. The SCFA are from de novo synthesis, LCFA are from the diet or body fat depots, and 16-C fatty acids can be synthesized or come from the diet or fat depots. As lactation progressed from 35 to 125 DIM, concentrations of SCFA and C16:0 increased and concentration of LCFA decreased (linear and quadratic 
Table 7. Changes in milk fatty acids over time averaged across dietary treatments (\% of total fatty acids)

\begin{tabular}{lcccccl}
\hline & & & & & \multicolumn{2}{c}{ Effect $^{2}$} \\
\cline { 5 - 7 } Fatty acid $^{1}$ & 35 DIM & 75 DIM & 125 DIM & SEM & Time & Int \\
\hline $4: 0$ & 3.70 & 4.11 & 3.39 & 0.07 & L, Q & TRF \\
$6: 0$ & 2.65 & 2.84 & 2.53 & 0.06 & L, Q & - \\
$8: 0$ & 1.34 & 1.53 & 1.36 & 0.04 & Q & - \\
$10: 0$ & 2.79 & 3.57 & 3.25 & 0.08 & L, Q & - \\
$12: 0$ & 2.97 & 4.05 & 3.88 & 0.09 & L, Q & TF \\
$14: 0$ & 9.82 & 12.3 & 12.3 & 0.15 & L, Q & TR, TR \\
$14: 1$ & 0.73 & 1.08 & 1.33 & 0.04 & L, Q & TF, TRF \\
$16: 0$ & 27.4 & 30.7 & 31.8 & 0.31 & L, Q & TF \\
$16: 1$ & 2.13 & 1.94 & 2.30 & 0.06 & L, Q & TRF \\
$18: 0$ & 10.8 & 8.82 & 8.30 & 0.26 & L, Q & TR \\
$18: 1 \quad c-9$ & 24.3 & 18.0 & 18.3 & 0.36 & L, Q & TF, TR \\
$18: 1 \quad c-11$ & 0.98 & 0.74 & 0.77 & 0.03 & L, Q & - \\
$18: 2$ & 3.66 & 3.45 & 3.42 & 0.08 & L & - \\
$18: 3$ & 0.63 & 0.56 & 0.56 & 0.01 & L, Q & - \\
$c-9, t-11$ CLA & 0.50 & 0.40 & 0.48 & 0.02 & Q & - \\
SCFA & 23.3 & 28.4 & 26.7 & 0.38 & L, Q & TF \\
LCFA & 44.4 & 35.5 & 35.4 & 0.55 & L, Q & TF \\
\hline
\end{tabular}

${ }^{1}$ Number of carbon atoms:number of double bonds $(c=$ cis, $t=$ trans $)$. CLA $=$ conjugated linoleic acid; SCFA $=$ short-chain fatty acids $(\leq 14 \mathrm{C}) ; \mathrm{LCFA}=$ long-chain fatty acids $(\geq 18 \mathrm{C})$. Fatty acids not shown were not affected by stage of lactation.

${ }^{2} \mathrm{~L}=$ linear time effect, $\mathrm{Q}=$ quadratic time effect $(P<0.05)$. Int $=$ interaction; $\mathrm{TF}=$ time $\times$ fat interaction, $\mathrm{TR}=$ time $\times$ forage:concentrate ratio interaction, $\mathrm{TRF}=3$-way interaction $(P<0.05)$.

effects for all 3 variables; $P<0.01$ ). The time effect is caused by change in nutrient intake and partitioning of energy between milk and body reserves (Figures 1, $2,3)$. In early lactation, DMI is low, which reduces substrate for de novo synthesis (reduced concentrations of SCFA and maybe C16:0) and increases mobilization of body fat reserves (increased concentrations of LCFA and perhaps greater concentrations of C16:0). As lactation progresses, body fat mobilization is reduced and eventually body reserves increase (less LCFA) and more substrate is consumed (more SCFA). The time effects we observed were similar to those in previous reports (Palmquist et al., 1993; van Knegsel et al., 2007).

In early lactation (35 DIM), the average cow on all treatments was losing BW and BCS (Figure 1) and the concentration of LCFA was higher than at other time points, reflecting mobilization of body fat stores into milk fat. Mobilization may have overshadowed dietary factors because at that time period, dietary treatments had few effects on milk fatty acids (supplementing fat increased 16:0 and 18:0 and decreased cis-9 18:1). At 75 and 125 DIM, the average cow on all treatments was gaining BW and BCS and fat treatment affected most fatty acids (Tables 5 and 6 ). Feeding fat decreased SCFA and increased LCFA at both time points, reflecting changes in the composition of dietary fatty acids. Dietary fat effects on 16:0 were less consistent. At 35 and 75 DIM, fat supplementation increased the concentration of $16: 0$ by about 2 percentage units $(P<0.05$ at both sampling times), but the increase was only 0.8 units $(P<0.20)$ at 125 DIM. Overall, changes in milk fatty acids when fat was supplemented largely reflected changes in the composition of fatty acids in the diet (Table 2).

The only consistent forage effect across lactation was higher 18:2 in milk from cows fed the low-forage diets, which reflected concentrations of dietary 18:2 (Table 2). At 35 DIM, the concentration of trans-10 18:1 increased when the low-forage diets were fed. Concentrations of trans-10 18:1 often increase when ruminal $\mathrm{pH}$ and milk fat percentage is depressed (Griinari et al., 1998). The low-forage diets were formulated to have lower concentrations of starch and higher concentrations of NDF, which should moderate ruminal $\mathrm{pH}$; however, DMI was higher for the low-forage diets, which would have increased the amount of fermentable organic matter consumed, which in turn might have reduced ruminal $\mathrm{pH}$. An increase in the concentration of trans-10 18:1 is often related to a reduction in milk fat concentration, but milk fat percentage was not affected by forage treatment at 35 DIM $(P>0.3$; data not shown). Forage treatment did not affect concentrations of 18:1 trans-10 at $75(P=0.49)$ or at 125 DIM $(P=0.78)$. At 125 DIM, feeding high-forage diets generally increased SCFA and decreased LCFA. This change could be the result of increased partitioning of LCFA to body reserves (van Knegsel et al., 2007) by cows fed the high-forage diets, but this is not supported by BCS or BW data (Figure 1). More likely, the forage effect at this time point reflects diet fatty acid composition (Table 2). 
Essentially no interactions were observed between fat and forage treatments for milk fatty acids at 35 and 75 DIM (the exception was trans-6,8 C 18:1). More interactions were observed at 125 DIM but most involved minor fatty acids and the biological significance is unclear. The interaction for trans-10 C18:1 (i.e., fat supplementation reduced the concentration in high-forage diets but had essentially no effect in low-forage diets) could reflect changes in starch concentrations (Table 2 ); however, no interaction was observed for milk fat percent at that same time point (data not shown).

Feeding the low-forage diets increased $(P<0.05)$ yields of milk protein and lactose but did not affect their concentrations. Increased yield of lactose may have been a result of increased supply of glucogenic precursors that occurred via a change in ruminal fermentation (i.e., increased propionic acid) or by an increase in DMI. When forages were replaced with soyhulls (in our experiment several byproducts, including soyhulls, replaced forage), ruminal propionate increased in most studies (Ipharraguerre and Clark, 2003). Our diets were formulated to contain similar concentrations of RDP and digestible RUP (estimated using NRC, 2001). However, the increased DMI by cows fed low-forage diets resulted in increased intake of RUP and probably increased production of microbial protein, both of which could have increased milk protein. High- and low-forage diets also differed in source of RUP (Table 1), which could have affected milk protein yield. Rumen-inert fats usually do not affect milk protein yields but can reduce milk protein concentration (Onetti and Grummer, 2004). In this study, fat did not affect milk yield and therefore no effect on protein concentration was observed.

Cows fed the low-forage diets had much lower $(P$ $<0.01$ ) concentrations of MUN than cows fed the high-forage diets (12.9 vs .15.1 mg/dL). The low- and high-forage diets differed markedly in protein and carbohydrate sources, both of which can influence MUN (Broderick and Clayton, 1997, Hristov and Ropp, 2003). Compared with the high-forage diets, the low-forage diets probably had a higher ratio of rumen-fermentable OM to RDP, which would reduce MUN. Fat supplementation also increased MUN (14.5 vs. $13.4 \mathrm{mg} / \mathrm{dL}$; $P<0.05)$. The added fat replaced corn grain in the diets and, specifically, starch from corn grain (Table 1). The likely reason fat increased MUN is that the amount of rumen-fermentable OM was reduced, which reduced the capture of RDP into microbial protein. In higher starch, lower fiber diets, fat supplementation has either not affected MUN (Harvatine and Allen, 2006) or reduced it (Rodriguez et al., 1997).

\section{CONCLUSIONS}

Replacing forage with a mixture of byproducts or replacing corn grain with saturated free fatty acids resulted in an increase in $\mathrm{NE}_{\mathrm{L}}$ intake. The forage effect was caused by increased DMI and the fat effect was caused by increased energy density. When high-forage diets were supplemented with fat, the increased $\mathrm{NE}_{\mathrm{L}}$ intake was directed mostly to body reserves but when fat was added to the low-forage diets, the energy was directed mostly to milk production. In early lactation, the lower DMI by cows fed the high-forage diet may have caused nutrients other than energy to be limiting for milk production.

\section{ACKNOWLEDGMENTS}

Salaries and research support provided by state and federal funds appropriated to the Ohio Agricultural Research and Development Center, The Ohio State University (Wooster). Additional support provided by Milk Specialities Global (Carpentersville, IL). We thank A. F. Kertz (Andhil LLC, St. Louis, MO) for his input in the design of this experiment.

\section{REFERENCES}

Allen, M. S. 2000. Effects of diet on short-term regulation of feed intake by lactating dairy cows. J. Dairy Sci. 83:1598-1624.

Association of Official Analytical Chemists. 2000. Official Methods of Analysis of AOAC International. Vol. 1 and 2. 17th ed. AOAC International, Gaithersburg, MD.

Broderick, G. A., and M. K. Clayton. 1997. A statistical evaluation of animal and nutritional factors influencing concentrations of milk urea nitrogen. J. Dairy Sci. 80:2964-2971.

Canale, C. J., P. L. Burgess, L. D. Muller, and G. A. Varga. 1990 Calcium salts of fatty acids in diets that differ in neutral detergent fiber: Effect on lactation performance and nutrient digestibility. J. Dairy Sci. 73:1031-1038.

Chilliard, Y. 1993. Dietary fat and adipose tissue metabolism in ruminants, pigs, and rodents: A review. J. Dairy Sci. 76:38973931.

Conrad, H. R., A. D. Pratt, and J. W. Hibbs. 1964. Regulation of feed intake in dairy cows. I. Change in importance of physical and physiological factors with increasing digestibility. J. Dairy Sci. 47:54-62.

Drackley, J. K., D. W. LaCount, J. P. Elliott, T. H. Klusmeyer, T. R. Overton, J. H. Clark, and S. A. Blum. 1998. Supplemental fat and nicotinic acid for Holstein cows during an entire lactation. J. Dairy Sci. 81:201-214.

Grant, R. J., and S. J. Weidner. 1992. Effect of fat from whole soybeans on performance of dairy cows fed rations differing in fiber level and particle size. J. Dairy Sci. 75:2742-2751.

Griinari, J. M., D. A. Dwyer, M. A. McGuire, D. E. Bauman, D. L. Palmquist, and K. V. V. Nurmela. 1998. Trans-octadecenoic acids and milk fat depression in lactating dairy cows. J. Dairy Sci. $81: 1251-1261$.

Harvatine, K. J., and M. S. Allen. 2006. Effects of fatty acid supplements on milk yield and energy balance of lactating dairy cows. J. Dairy Sci. 89:1081-1091. 
Hristov, A. N., and J. K. Ropp. 2003. Effect of dietary carbohydrate composition and availability on utilization of ruminal ammonia nitrogen for milk protein synthesis in dairy cows. J. Dairy Sci. $86: 2416-2427$.

Ipharraguerre, I. R., and J. H. Clark. 2003. Soyhulls as an alternative feed for lactating dairy cows: A review. J. Dairy Sci. 86:10521073.

Jerred, M. J., D. J. Carroll, D. K. Combs, and R. R. Grummer. 1990. Effects of fat supplementation and immature alfalfa to concentrate ratio on lactation performance of dairy cattle. J. Dairy Sci. $73: 2842-2854$.

Klusmeyer, T. H., G. L. Lynch, J. H. Clark, and D. R. Nelson. 1991. Effects of calcium salts of fatty acids and proportion of forage in diet on ruminal fermentation and nutrient flow to duodenum of cows. J. Dairy Sci. 74:2220-2232.

NRC. 2001. Nutrient Requirements of Dairy Cattle. 7th rev. ed. Natl. Acad. Press, Washington, DC.

Onetti, S. G., and R. R. Grummer. 2004. Response of lactating cows to three supplemental fat sources as affected by forage in the diet and stage of lactation: A meta-analysis of literature. Anim. Feed Sci. Technol. 115:65-82.

Palmquist, D. L., A. D. Beaulieu, and D. M. Barbano. 1993. Feed and animal factors influencing milk fat composition. J. Dairy Sci. $76: 1753-1771$
Relling, A. E., and C. K. Reynolds. 2007. Feeding rumen-inert fats differing in their degree of saturation decreases intake and increases plasma concentrations of gut peptides in lactating dairy cows. J. Dairy Sci. 90:1506-1515.

Rodriguez, L. A., C. C. Stallings, J. R. Herbein, and M. L. McGilliard. 1997. Effect of degradability of dietary protein and fat on ruminal, blood, and milk components in Jersey and Holstein cows. J. Dairy Sci. 80:353-363.

SAS Institute. 2004. SAS/STAT User's Guide. Version 9. SAS Institute Inc., Cary, NC.

van Knegsel, A. T. M. H. von der Brand, J. Dijkstra, W. M. von Straalen, M. J. W. Heetkamp, S. Tamminga, and B. Kemp. 2007. Dietary energy source in dairy cows in early lactation: Energy partitioning and milk composition. J. Dairy Sci. 90:1467-1476.

Weiss, W. P., and D. J. Wyatt. 2000. Effect of oil content and kernel processing of corn silage on digestibility and milk production by dairy cows. J. Dairy Sci. 83:351-358.

Weiss, W. P., and D. J. Wyatt. 2003. Effect of dietary fat and vitamin $\mathrm{E}$ on alpha-tocopherol in milk from dairy cows. J. Dairy Sci. $86: 3582-3591$. 